\title{
Management of Anesthesia in a Pregnant with Behçet's Disease
}

\author{
Behçet Hastalığı Olan Gebede Anestezi Yönetimi
}

\author{
Erdinç Koca, Hasan Șayan \\ Malatya State Hospital, Department of Anesthesiology and Reanimation, Malatya, Turkey
}

\begin{abstract}
Behçet's disease was described by Dr. Hulusi Behçet in 1937. Behçet's disease is an inflammatory multisystem disease including recurrent oral and genital ulcers, eye and skin symptoms, joint, vein and nervous system involvement. Especially the scar tissue formed due to recurrent oral ulcers causes difficult intubation and ventilation. Also the drugs used for treatment may cause adverse effects on many organs. It has great importance for anesthesia choice due to multiple organ involvement. Our case was a 38-year old woman, who has been diagnosed as Behçet's, caesarean section was planned at 38 weeks of gestation. Behçet's disease and pregnancy are both important for the anesthesia management. It was planned as a general anesthesia for the patient because it was not thought to be a difficult airway management. In this case report the general anesthesia management of the patient with Behçet's Disease was discussed.
\end{abstract}

Key words: Behçet's disease; pregnancy; anesthesia

\section{ÖZET}

Behçet hastalığı Dr. Hulusi Behçet tarafından 1937'de tanımlanmıștır. Behçet hastalığı tekrarlayan oral ve genital ülserlerin görüldügü, göz, deri, eklem, damar, sinir sistemi tutulumu gösteren multisistemik iltihabi bir hastalıktır. Özellikle tekrarlayan oral ülserlere bağlı olușan skar dokusu entübasyon ve ventilasyonu zorlaștırmaktadır. Birçok organ tutulumu nedeni ile anestezi seçimi önem arz eder. Ayrıca tedavide kullanılan ilaçlar birçok organ üzerinde yan etki olușturabilir. Olgu, 38 yașında, 38 haftalık gebeliği olan ve sezaryen planlanan Behçet hastasıydı. Hem Behçet hastalığı hem de gebelik, anestezi yönetimi açısından önemlidir. Hastada öncelikli olarak zor havayolu düșünülmediği için genel anestezi planlandı. Bu olgu sunumunda Behçet hastası olan bir hastada genel anestezi yönetimi tartıșılmıștır.

Anahtar kelimeler: Behçet hastalığı; gebelik; anestezi

Hasan Sayan, Malatya Devlet Hastanesi, Yesilyurt, Malatya - Türkiye, Tel.05354903917Email.drhasansayan@hotmail.com

Gelis Taribi: 23.03.2016 • Kabul Taribi: 26.05.2017

\section{Introduction}

Behçet's disease (BD) was described for the first time in 1937 by Professor Dr. Hulusi Behçet. BD was defined as a multisystem inflammatory disease including recurrent oral and genital ulcers, joint, vascular and neurological involvement ${ }^{1}$. Vasculitis of venules is regarded as histopathological lesions in $\mathrm{BD}^{2}$. The incidence of the disease was found as 110-420/100 000 in Turkey ${ }^{3}$. It is known that the disease is more commonly seen in males aged between 20-35 years and is more severe in this group ${ }^{4}$. BD is a multisystem disease for this, the anesthesia management has a significant importance. Especially the scar tissue formed due to recurrent oral ulcers causes difficult intubation and ventilation ${ }^{5}$. In addition, depending on the drug used in the treatment of BD a number of changes occur in the gastrointestinal, immune and endocrine systems. These changes should be reminded for anesthesia choice. The long-term use of colchicine may cause impaired liver and kidney function. With all these aspects the selection of anesthesia has a particular importance in this disease ${ }^{6}$.

\section{Case Report}

A-38 year-old, 38 weeks G3P2A1, $165 \mathrm{~cm}$ tall, $82 \mathrm{~kg}$, female patient was planned for elective surgery. In her history; she was diagnosed $\mathrm{BD}$ when she was went to the doctor for visual impairment 5 years ago and was followed for 5 years. She was taking azathioprine 50 $\mathrm{mg}$, cyclosporine $100 \mathrm{mg}$. She had released the medication due to pregnancy. Her physical classification was considered as American Society of Anesthesiologists (ASA) II. In the preoperative examination the Mallampati score was II and there was no scar tissue in her mouth. Blood count, liver and kidney function 
tests, serum electrolytes, coagulation values were within the normal range and electrocardiogram was normal. She was consulted to neurology and ophthalmology departments. There was no neurologic pathology and the visual degree was found as $7 / 10$ for right eye and $6 / 10$ for left eye.

Non-invasive blood pressure, ECG, pulse oximetry monitoring was performed in the operating room. A vascular access was performed with a 22 -gauge intracath on her right arm. Ranitidine $\mathrm{HCl} 50 \mathrm{mg}$ and metoclopramide $10 \mathrm{mg}$ iv were applied. Necessary equipment for difficult airway management was kept ready. Preoxygenation was achieved. Propofol 200 $\mathrm{mg}$ and rocuronium bromide $50 \mathrm{mg}$ iv were administered. The patient was intubated and the surgery was performed. Operation lasted about 45 minutes. A-2960 g boy baby was delivered by caesarean. The patient was followed closely during intraoperative and postoperative period and there was no problem. Postoperative first and third days neurological and visual examination was performed. The patient was discharged on the postoperative third day and she was normal.

\section{Discussion}

$\mathrm{BD}$ is an inflammatory disease with unknown etiology involving primarily the skin lesions but may also affect many organs and systems. It may cause intubation and ventilation difficulties due to the adhesions depending on ulcer healing scar tissue in especially oropharyngeal space. In addition intubation procedure, itself may lead to ulcer formation in the postoperative period ${ }^{7}$. The thyromental, sternomental distances, mouth opening, neck movements were all within normal range in the preoperative examination of our patient and we did not foresee any difficulties in airway control. We performed the intubation at once easily and we did not find any lesion in her mouth, before and after the intubation procedure.

Noel et al. was reported that the patients who received colchicine treatment had better prognosis than patients who did not receive colchicine and he reported an increase in the central nervous system involvement and ocular lesions in patients who did not receive the treatment ${ }^{7}$.

Bang et al. reported an improvement in nine patients while an exacerbation in 18 patients, in their study on 27 pregnant woman with $\mathrm{BD}^{8}$. Marshal et al. reported a pregnant women that developed Budd-Chiari syndrome and there was no deterioration in other patients that they followed up 9 . In our case, the patient had discontinued her drugs with the onset of pregnancy, but the disease remained stable during this period and the patient did not show any sign of disease.

Salihoğlu et al reported a case report about their experience with a BD patient in whom intubation could be performed after four attempts. Also, they reported that, they observed aphthous lesions in oral mucosa, tongue, gums, lips, and larynx in this patient postoperatively ${ }^{10}$. Bhardwaj et al. reported an orotracheal intubation experience by the help of fiber optic bronchoscopy in a 14-year-old patient with mucosal scar tissue ${ }^{11}$. Due to the involvement of many systems in $\mathrm{BD}$, in the postoperative period cardiac, pulmonary and renal complications may be seen in high incidence $^{12}$. Especially colchicine may cause deterioration of liver and kidney function due to chronic use. This condition can prolong the elimination of drugs like muscle relaxants, iv general anesthetics from the body ${ }^{13}$. In this aspect the close monitoring of patients in the postoperative period, especially if they have received general anesthesia is very important. The liver and kidney functions of our patient were normal and we did not observe any complications in the postoperative period.

Neurological involvement in BD may be determined in an average of five years after the onset of systemic symptoms. Ataxia, hemiparesis, sphincter dysfunction, behavioral changes, cognitive dysfunction and epileptic seizures can be seen due to neurological involvement ${ }^{14}$. The increase in intracranial pressure in patients with central nervous system involvement forms contraindication for regional anesthesia. For this reason, patients who are planned for regional anesthesia should be evaluated in detail with appropriate preoperative imaging techniques ${ }^{15}$.

In our patient we could not use any neuroimaging scan because of the pregnancy and we preferred general anesthesia primarily. Although we did not see neurological symptoms, we preferred general anesthesia due to the possibility of airway difficulties.

General anesthesia should be chosen in patients with $\mathrm{BD}$, when difficult airway management is being considered and these patients should be monitored closely for the detection of possible complications in the postoperative period. 


\section{References}

1. Behçet $\mathrm{H}$. Uber rezideverende aphtose, duch ein virüs verursachte geschwure am mund, am auge und den genitalien. Derm Wochenschr 1937;36:1152-7.

2. Türköz A, Toprak IH, Köroğlu A, But AK, Toprak Hİ, Ersoy ME. Anesthetic management and endovascular stent grafting of abdominal aortic aneurysm in a patient with Behçet's disease. J Cardiothorac Vasc Anesth 2002;16:468-70.

3. Idil A, Gürler A, Boyvat A, Caliskan D, Ozdemir O, Isik A, et al. The prevalence of Behçet's disease above the age of 10 years. The results of a pilot study conducted at the Park Primary Health Care Center in Ankara, Turkey. Ophthalmic Epidemiol 2002;9:325-31.

4. Özbalkan Z, Bilgen ŞA. Behçet's disease. Hacettepe Med J 2006;37:14-20.

5. Turner ME. Anaesthetic difficulties associated with Behçet's syndrome. Case report. Br J Anaesth 1972;44:100-2.

6. Goz M, Cakir O, Eren MN. Behçet's Syndrome: Is Ligation an Alternative Treatment? Vascular 2007;15(1):46-8.

7. Noel N, Wechsler B, Nizard J, Costedoat CN, Boutindu LT, Dommergues $\mathrm{M}$, et al. Behçet's disease and pregnancy. Arthritis Rheum 2013;65:2450-6.
8. Bang D, Chun YS, Haam IB, Lee E-S, Lee S. The influence of pregnancy on Behçet's Disease. Yonsei Med J 2007;38:437-43.

9. Marsal S, Falga C, Simeon CP, Vilardell M, Bosch JA. Behçet's Disease And Pregnancy Relationship Study. Br J Rheumatol 1997;36:234-8

10. Salihoglu Z, Dikmen Y, Demiroluk S, Hamzaoglu I, Paksoy M. Oral aphthous ulcers after difficult intubation in a patient with Behçet's disease. Anaesthesia 2002;57:620-1.

11. Bhardwaj M, Singh K, Taxak S. Oral Scarring in Behçet's Disease An Airway Concern. J Anesthe Clinic Res 2012;3:183.

12. Berkow R. The Merc Manuel Teşhis ve Tedavi El Kitabı. Çeviri. Pekus M, İstanbul, Merc Yay 1985:905-6.

13. Ertürk E, Şenel AC, Koşucu M, Kaya F, Erciyes N. Behçet Hastalığında Anestezi Uygulaması -Rejyonal mi, genel mi? Türk Anest Rean Der Derg 2009;37(2):114-7.

14. Porcu P, Chavanon O, Bertrand B, Costache V, Carley H, Bach V, et al. Giant aneurysm of the proximal segment of the left anterior descending artery in a patient with Behçet's disease-a combined approach. Canadian J Cardiol 2008;24(10):73-4.

15. Özcan A, Balcı C, Aksoy ŞM. Behçet hastasında anestezi yönetimi. Medeniyet Medical Journal. 2015;30(1):60-2. 